\title{
Let's be sensible about public participation
}

\section{We must face the fact that science - like art - is not a democratic activity.}

Sir - Your Editorial "Going public" (Nature 431, 883; 2004), like the think-tank Demos, supports the fashionable demand by a group of sociologists for more democratic science, including more 'upstream' engagement of the public and its involvement in setting research priorities. Demos goes further and supports a 'needs test' for licensing new products or services by companies. It also argues that we, the public, should know who owns and controls new technologies, and who benefits, before they are developed.

If the Demos policy had been followed in the past, we would have neither electricity nor the laser, to name only two examples, because no practical uses were foreseen for either. As your Editorial admits, public-engagement exercises in the United States have led patient lobby groups to press the National Institutes of Health for less basic research and more drug development. Because of public demand, large sums are spent on developing drugs with Viagra-like properties rather than on medicines for people in developing countries, and a widespread public consultation exercise in Oregon has found strong opposition to spending limited public funds on AIDS or mental health.

In practice, greater involvement of 'the public' in the 'upstream' development stage of science means involvement of specialinterest groups. When the UK Agriculture and Environment Biotechnology Commission was set up, the 'public' representatives were the chair of Greenpeace, the chair of the Soil Association, the executive director of GeneWatch and the programme adviser to the Green Alliance. No wonder the 'GM Nation' exercise in public consultation was a fiasco.
Of course democratically elected governments must decide how public funds for science are allocated. Of course sensible consultation helps development of policy: the debate on stem-cell research in the United Kingdom was a good example. Of course more openness and transparency are to be encouraged where possible. But let us not display unthinking subservience to the principle of participation. In Britain, involvement by victims of rail accidents in deciding policy on railway safety has led to the investment of billions of pounds to save some five lives a year. Meanwhile, twice that number die on British roads every day. The fact is that science, like art, is not a democratic activity. You do not decide by referendum whether the Earth goes round the Sun.

Dick Taverne

Chair of Sense About Science, House of Lords, London SW1A OPW, UK

\section{Public participation: let the people pick projects}

Sir - Your editorial "Going Public" (Nature 431, 883; 2004) makes a persuasive case for upstream public engagement in science funding. No doubt setting up committees of non-scientists to advise the existing funding bodies is a step in the right direction. But there is also a more radical possibility, namely to set aside a small proportion of the public science budget, say $1 \%$, for research proposed by lay people.

What questions would be of public interest? Why not ask? Organizations such as charities, schools, local authorities, trades unions, environmental groups and gardening associations could be invited to make suggestions. Within each organization, the very possibility of proposing research could trigger far-ranging discussions and would lead to a sense of involvement in many sections of the population.

To avoid the $1 \%$ fund being taken over by the science establishment, it would need to be administered by a board largely composed of non-scientists, as in many research charities. Funding would be restricted to areas not already covered by the other $99 \%$ of the public science budget.

This system could be treated as an experiment and tried out for, say, five years. If it had no useful effects, it could be discontinued. If it led to productive research, greater public trust in science and increased interest among students, the percentage allocated to this fund could be increased.

Rupert Sheldrake

20 Willow Road, London NW3 1TJ, UK

\section{Bible study led Newton to scientific discoveries}

Sir - I feel that your News story "Newton's religious screeds get online airing" (Nature 430, 819; 2004) rather misses the point. To our modern minds, Isaac Newton's religious ideas may indeed seem "unorthodox" or "radical", but they did not look like this to his contemporaries. Like another father of modern science, Francis Bacon (see "A modern kind of magic", Nature 418, 821; 2002), Newton strongly believed that he lived in an era that had been predicted by the Book of Daniel of the Old Testament, a time when knowledge was expected to grow beyond recognition.

Throughout his life, Newton tested biblical truth against the physical truths of experimental and theoretical science. He never observed a contradiction. The order that he found in nature through experiment and calculation - later to be called the mechanistic worldview - was for him God's work, and proof of God's work in history, which he extracted from the Bible. Astronomical calculations helped him to synchronize biblical events described in the Old and New Testaments with what he knew about ancient, medieval and modern history.

To English Protestants during the seventeenth century, when the country was consumed by apocalyptic zeal, the Book of Daniel and The Apocalypse, or The Revelation of St John, were history revealed truth - even though they were written in visionary and symbolic language. The task was to turn these visions and symbols into modern language.

A whole host of scientific writers including the illustrious Cambridge polymath Joseph Mede — took to the task of interpretation. It was on the shoulders of these giants that Newton was standing when he wrote his main religious work Observations upon the Prophecies of Daniel and the Apocalypse of St John, which was intended as an update of world history based on the five-kingdoms scheme in the Book of Daniel.

It is probably one of the deepest ironies in the history of science that Newton's brilliant work did not serve the purpose that he intended. Rather than proving the Bible right, it led to the birth of science as we know it - that is, experimental natural science.

We now know that the Book of Daniel's five-kingdoms scheme is a myth and The Revelation of St John is a wonderful fairy tale. But it is the Bible, nevertheless, that stands, in a very literal sense, at the origin of modern science.

Erwin Heberle-Bors

Vienna Biocenter, Dr Bohrgasse 9,

A-1030 Vienna, Austria 